\title{
38. MINERALOGY OF SANDS FROM THE BENGAL AND NICOBAR FANS, SITES 218 AND 211, EASTERN INDIAN OCEAN
}

\author{
Robert W. Thompson, Humbolt State College, Arcata, California
}

\section{INTRODUCTION}

Terrigenous sands and silts of turbidite origin were encountered at two sites during Leg 22 , Site 218 on the central Bengal Fan $\left(08^{\circ} 0.4^{\prime} \mathrm{N}, 86^{\circ} 17.0^{\prime} \mathrm{E}\right)$ and Site 211 near the southeastern extreme of the Nicobar Fan $\left(09^{\circ} 46.5^{\prime} \mathrm{S}\right.$, $\left.102^{\circ} 41.9^{\prime} \mathrm{E}\right)$. Curray and Moore (1971; personal communication, 1973) proposed that the bulk of the sediments comprising the Bengal Fan and probably most of those of the Nicobar Fan represents erosion products of the Himalayas. The sediments are supplied to the north end of the Bay of Bengal largely by the Ganges and Brahmaputra rivers, and thence dispersed southward by turbidity currents via the Swatch of No Ground and multiple north-south trending fan valleys. They further suggested the possibility of at least two, more or less distinct, episodes of turbidite deposition on the Bengal Fan, late MiocenePliocene and Quaternary, and that these reflect major Himalayan orogenies of the middle Miocene and latest Pliocene to Pleistocene. Sampling and dating of the sediments from these two turbidite "units" were the primary purposes for drilling at Site 218 .

The mineralogical investigation discussed in this paper was undertaken with the following objectives:

1) to examine the likelihood of the same sediment source for the turbidites at Sites 218 and 211 and to see if the mineral suite is consistent with what might be expected from a source terrain such as the Himalayas;

2) to look for any significant differences or trends in mineral assemblage down the hole at Site 218 which indicate changes in provenance through time.

Details regarding the stratigraphic sections encountered at these sites are given in Chapters 2 and 9.

\section{METHODS AND RESULTS}

Heavy minerals were examined from 18 samples spaced down through the cored section at Site 218 and 4 samples from Site 211. Most of the samples studied (17) are from relatively coarse interbeds and are classed texturally as silt, sandy silt, or silty sand. Five samples are from clayey silt beds.

All samples were initially sieved and the sand fraction between 62 and 250 microns was selected for analysis. Cursory microscopic examination showed that the very small fractions coarser than 250 microns consist mainly of reddish brown biotite along with some feldspar and quartz. The samples were pretreated in dilute hydrochloric acid and stannous chloride to remove carbonate and iron-oxide grain coatings. Separations into light and heavy mineral fractions were made by settling in tetrabromoethane (specific gravity $=2.89)$. In this procedure some of the very abundant biotite settled, some did not, hence this was not included in the mineral counts with the exception that a part of the opaque category may include thick mica grains.

Among the heavy minerals, which constitute from $0.2 \%$ to $7 \%$ of the sand fraction, the most common constituents (generally $>5 \%$ ) include: hornblende $(30-60 \%)$, epidote plus zoisite $(10-30 \%)$, garnet $(3-16 \%)$, and pyroxenemainly augite $(2-13 \%)$ (Table 1$)$. Persistent accessory minerals (generally $<5 \%$ ) include: apatite, kyanite, sillimanite, staurolite, titanite (sphene), tourmaline, and tremolite. Anatase, glaucophane, hypersthene, rutile, and zircon are present in many samples (usually $>1 \%$ ) and comprise most of the minerals listed as "others" in Table 1. Altered grains, many of which are thought to be epidote and zoisite, persist throughout the section but are particularly common (up to 25\%) below a depth of about 270 meters at Site 218. Opaques fluctuate erratically through the section with abundance ranging from $2 \%$ to $24 \%$ of the total heavy fraction. No attempt was made to differentiate the opaque minerals.

\section{DISCUSSION}

The heavy mineral assemblage in samples from both sites appears similar in general aspect and indicates derivation of these sediments from a complex source dominated by lowto high-rank metamorphic and acid igneous rocks. Perusal of geologic maps by Gansser (1964) shows the prevalence of granite-grandiorite, gneiss, schist, slate, and calcareous phyllite in the drainage basins of the Ganges and Brahmaputra rivers; thus, a Himalayan source is consistent with the mineralogic evidence. For Site 211, this implies transport of sand from the head of the Bay of Bengal and down the Nicobar Fan east of Ninetyeast Ridge for a distance on the order of $3500 \mathrm{~km}$.

To test for possible trends in mineral composition at Site 218 which might reflect changes in provenance, the heavy minerals were grouped into suites as follows:

Suite 1: acid igneous and high-rank metamorphicapatite, hornblende, kyanite, monazite, sillimanite, staurolite, zircon

Suite 2: low-rank metamorphic-epidote (including zoisite), garnet, glaucophane, tourmaline, tremolite

Suite 3: basic igneous-hypersthene, pyroxene (mainly augite)

By considering the above-cited minerals plus altered grains to constitute the total assemblage, the percentage of each suite in each sample was calculated and plotted at the appropriate depth for Site 218 (Figure 1). For samples which are closely spaced vertically (e.g., 218-11-1, 218-11-2), an average of the percentages was plotted. Textural data as depicted in the site summary for Site 218 (Chapter 9) are also shown in Figure 1. 
TABLE 1

Nonopaque Heavy Mineral Composition of Bengal and Nicobar Fan Sediments at Sites 218 and 211

\begin{tabular}{|c|c|c|c|c|c|c|c|c|c|c|c|c|c|c|}
\hline Sample & $\begin{array}{c}\text { Depth } \\
\text { Interval } \\
(\mathrm{cm})\end{array}$ & 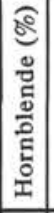 & 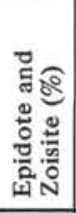 & 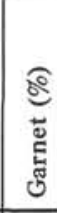 & 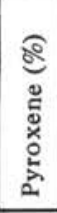 & 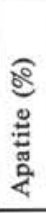 & 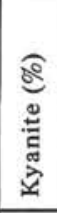 & 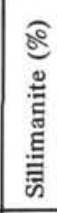 & 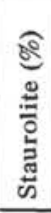 & 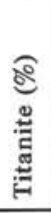 & 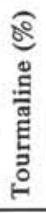 & 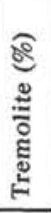 & 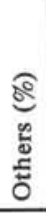 & 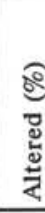 \\
\hline $218-2-5$ & $55-58$ & 55 & 14 & 7 & 8 & 3 & $\operatorname{tr}^{b}$ & $\mathrm{tr}^{\mathrm{b}}$ & 1 & 3 & tr & 5 & 3 & 1 \\
\hline $218-3-2$ & $136-139$ & 57 & 13 & 6 & 6 & 1 & 0 & 2 & 1 & 2 & 1 & 2 & 4 & 5 \\
\hline $218-4-2$ & $100-102$ & 50 & 17 & 7 & 7 & 5 & 0 & 0 & 0 & 2 & 1 & 5 & 7 & 0 \\
\hline $218-4-2$ & $109-111$ & 53 & 11 & 5 & 13 & 1 & 2 & 1 & tr & 3 & 1 & 5 & 3 & 1 \\
\hline $218-5-1$ & $51-53$ & 56 & 14 & 8 & 8 & 0 & 0 & 1 & 2 & 1 & 0 & 1 & 3 & 5 \\
\hline $218-9-1$ & $105-107$ & 55 & 9 & 10 & 9 & 4 & $\operatorname{tr}$ & $\operatorname{tr}$ & $\operatorname{tr}$ & 2 & 0 & 5 & 3 & 2 \\
\hline $218-10-1$ & $105-107$ & 45 & 12 & 15 & 4 & 1 & 4 & 1 & 1 & 1 & 4 & 4 & 6 & 2 \\
\hline $218-11-1$ & $139-141$ & 52 & 15 & 4 & 3 & 2 & $\operatorname{tr}$ & 0 & 1 & 3 & 3 & 7 & 5 & 5 \\
\hline $218-11-2$ & $100-103$ & 37 & 19 & 16 & 2 & 0 & 4 & 4 & 0 & 2 & 2 & 1 & 3 & 9 \\
\hline 218-14-1 & 89-91 & 39 & 12 & 9 & 2 & 1 & 1 & 5 & 1 & 3 & 4 & 1 & 4 & 17 \\
\hline 218-14-1 & $90-93$ & 37 & 20 & 6 & 6 & 2 & 3 & 3 & 2 & 1 & 4 & 0 & 3 & 13 \\
\hline $218-14, \mathrm{CC}$ & - & 36 & 13 & 5 & 2 & 0 & 0 & 1 & $\operatorname{tr}$ & 4 & 6 & 3 & 5 & 25 \\
\hline $218-17-3$ & $23-26$ & 53 & 13 & 8 & 3 & 1 & $\operatorname{tr}$ & 2 & 1 & 1 & 2 & 5 & 3 & 8 \\
\hline $218-20-1$ & $88-90$ & 48 & 11 & 10 & 3 & 0 & 0 & 3 & 2 & 4 & 3 & 2 & 4 & 8 \\
\hline $218-22-2$ & $65-68$ & 28 & 22 & 17 & 5 & 0 & 3 & 1 & 2 & 0 & 1 & 1 & 4 & 16 \\
\hline $218-25-2$ & $143-145$ & 33 & 16 & 15 & 3 & tr & $\operatorname{tr}$ & 3 & 2 & 1 & 4 & 1 & 3 & 19 \\
\hline $218-26-2$ & $133-135$ & 41 & 15 & 7 & 4 & 3 & 2 & 1 & 0 & 0 & 3 & 1 & 4 & 18 \\
\hline $218-27, \mathrm{CC}$ & - & 32 & 31 & 4 & 4 & 1 & 2 & 0 & 0 & 1 & 0 & 6 & 5 & 15 \\
\hline $211-4-2$ & $34-36$ & 50 & 3 & 9 & 3 & 1 & 1 & 4 & 0 & 3 & 5 & 4 & 5 & 12 \\
\hline $211-7-1$ & $100-145$ & 43 & 11 & 18 & 3 & 2 & 4 & 4 & 1 & 2 & 1 & 2 & 4 & 5 \\
\hline $211-8-1$ & $60-100$ & 42 & 11 & 17 & 3 & 0 & 1 & 3 & $\operatorname{tr}$ & 2 & 6 & 5 & 3 & 7 \\
\hline $211-9-3$ & $134-136$ & 52 & 12 & 6 & 4 & 2 & $\operatorname{tr}$ & 4 & $\operatorname{tr}$ & 3 & 5 & 3 & 3 & 5 \\
\hline
\end{tabular}

aPrincipally anatase, glaucophane, hypersthene, and zircon. $\mathrm{b}_{\mathrm{tr}}=$ trace.
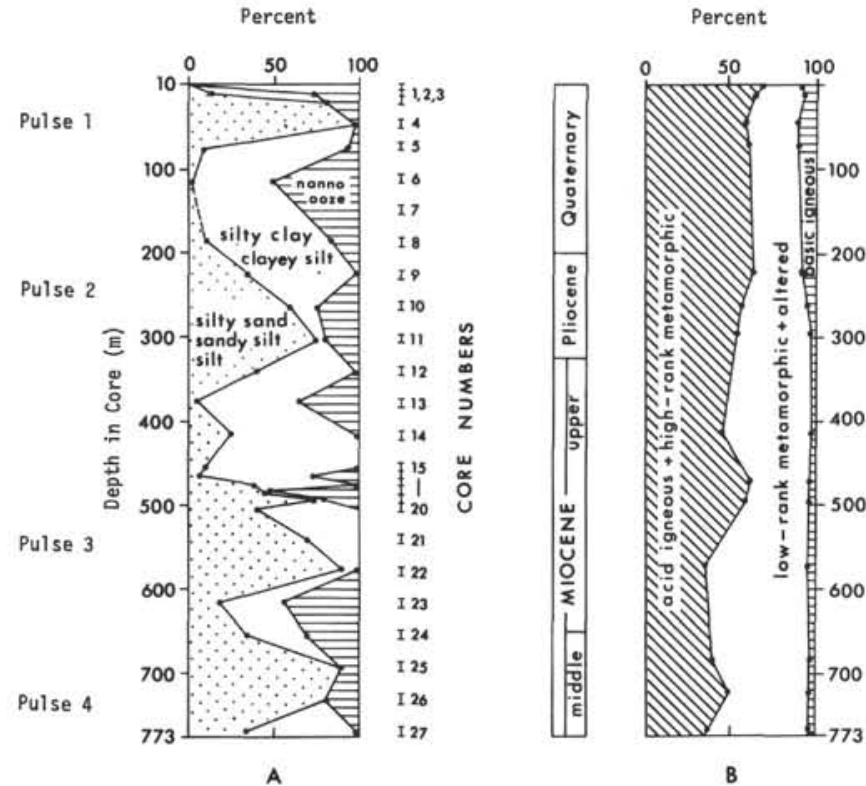

Figure 1. Vertical distribution of lithology $(A)$ and heavy mineral suites (B)-Site 218. Lithology: percent by thickness in each core. Mineralogy: percent by number in each sample.
Minerals comprising Suite 1 clearly predominate in the upper section from 0 to about 220 meters. Between 220 meters and about 550 meters, Suites 1 and 2 occur in roughly equal proportions, and below 550 meters the low-rank metamorphic suite generally predominates. Basic igneous minerals are clearly secondary throughout the section and show a general decline in relative abundance downward. The changing balance of mineral suites probably relates to progressive uplift of the Himalayas which was accompanied by stripping away the overburden of sedimentary and low-rank metamorphic rocks so that the core of high-rank metamorphics and acid intrusives has contributed an ever-increasing share of the material. This is consistent with the late Tertiary history mentioned earlier.

Superimposed upon and contributing to the gradual shift in mineral composition is another, more abrupt change in character of the suite between the depths of 220 and 270 meters. Above this depth interval, the mineral assemblage is dominated by hornblende $(>50 \%)$ with substantial epidote $(10-15 \%)$, garnet, and pyroxene (each $5-10 \%)$. Altered grains are relatively scarce as are the characteristic high-rank metamorphic minerals, sillimanite and kyanite (Figure 2). Below this depth, hornblende and pyroxene decrease substantially, whereas epidote, tourmaline, kyanite, sillimanite, and especially altered grains, increase quite abruptly. 


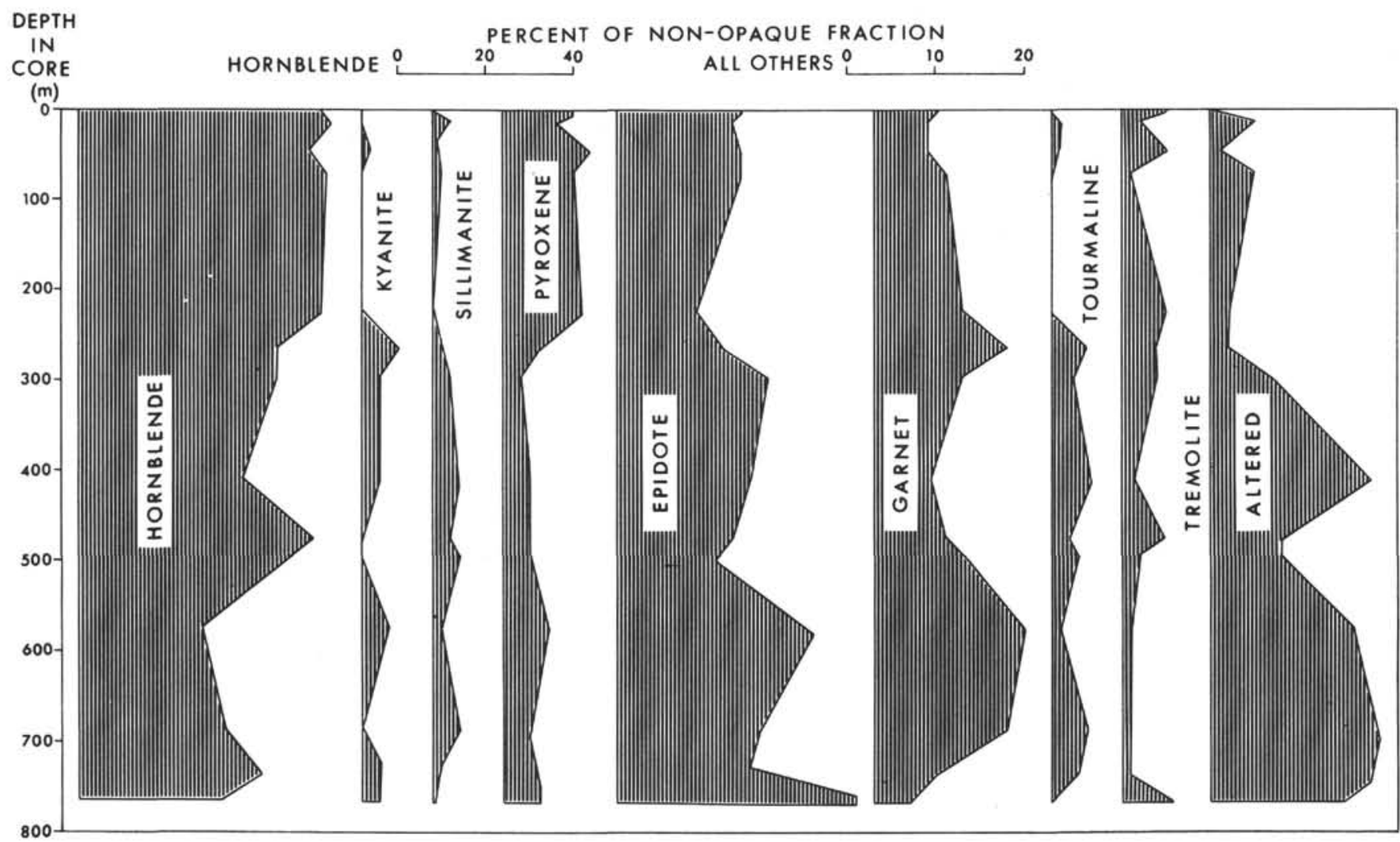

Figure 2. Vertical distribution of nonopaque heavy minerals-Site 218. Data from Table 1.

These changes, which occur in probable mid to upper Pliocene, are interpreted to reflect a marked increase in erosion rates during late Pliocene and Quaternary times resulting from a combination of substantial uplift and onset of glacial activity. The diminished abundance of relatively stable accessories in the upper section, then, is attributed to dilution by greater input of less stable minerals, in particular, hornblende. Probable corroboration for this interpretation is the observation that the principal change in mineralogy occurs a short distance above an unconformity which is recognized at about 360 meters depth on seismic reflection records and which Curray and Moore (Chapter 16) interpret to reflect a period of pronounced Himalayan upheaval.

The turbidite sands encountered at Site 211 are thought to be Pliocene in age. The mineral assemblage in these sediments corresponds most closely to that in Site 218 sediments between the depths of 180 and 380 meters.
These also are mainly Pliocene. Dispersal of a substantial portion of the incoming sediments to the Nicobar Fan during Pliocene time might account for the apparent slow deposition rates at Site 218 during this time interval. The termination of turbidite deposition at Site 211 in late Pliocene may relate to northward migration of the Ninetyeast Ridge, on the Indian-Australian plate, to the vicinity of the northern extension of the Java Trench. This would sever the sediment supply route from the head of the Bay of Bengal.

\section{REFERENCES}

Curray, J. R. and Moore, D. G., 1971. Growth of the Bengal deep-sea fan and denudation of the Himalayas: Geol. Soc. Am. Bull., v. 82, p. 563-572.

Gansser, A., 1964. Geology of the Himalayas: London (Interscience). 